\title{
Political Business Cycles and Endogenous Elections
}

\author{
Jac C. Heckelman* and Hakan Berument $\dagger$
}

\begin{abstract}
Empirical research of political business cycles (PBCs) may suffer from endogeneity bias when incumbent governments have discretion to call for an early election. Using an instrumental variable (IV) routine on data from Japan and the U.K., we find strong evidence to support the notion that election timing is a function of the economy rather than the macroeconomy being driven by elections as assumed in PBC. In single-equation regressions, no evidence of political cycles are found, but Hausman tests suggest elections are endogenous in our regressions. A monetary cycle in Japan and an inflation cycle in the U.K. are uncovered through IV estimation.
\end{abstract}

\section{Introduction}

The political business cycle (PBC) model as developed by Nordhaus (1975) suggests incumbent politicians have an incentive to stimulate the economy to bolster their reelection chances. This coincides with empirical evidence that favorable economic conditions impact upon incumbent popularity (Frey and Schneider 1978; Kirchgässner 1985; Chappell 1990) and voting patterns (Kramer 1971; Fair 1978; Chappell 1990) in an advantageous manner. If voters do behave in this fashion, politicians should be aware of this and consequently help themselves by spurring growth prior to an election. However, any stimulus the politicians can provide is expected to be short-lived; economic booms during the election period are followed by busts in the next period as the reelected government attempts to eliminate the newly created inflationary pressures on the economy.

PBC models have come under close scrutiny with mixed empirical results. Evidence of PBCs have been found in the U.S. for transfer payments (Tufte 1978) and monetary policy (Grier 1987) and in Britain for government expenditures and unemployment (Keil 1988). PBC models have been rejected in the U.S. for unemployment (McCallum 1978; Hibbs 1987a) and GNP (Hibbs 1987a; Heckelman and Whaples 1996) and in Japan for fiscal and monetary manipulation (Ito and Park 1988). In a comprehensive study of several OECD countries, Alesina, Cohen, and Roubini $(1992,1993)$ find limited supporting evidence for a variety of macroeconomic cycles and conclude by rejecting the implications of PBC. Nordhaus's (1975) original tests on unemployment cycles also yield mixed results for a few industrialized democracies.

However, another explicit assumption in Nordhaus's PBC model is that the election occurrence is fixed. As noted above, studies of the Nordhaus PBC have often tested his model on OECD countries where this assumption is violated. In most parliamentary-style nations, the

* Wake Forest University, P.O. Box 7505, Winston-Salem, NC 27109, USA; E-mail heckeljc@wfu.edu.

† Department of Economics, Bilkent University, 06533 Bilkent, Ankara, Turkey; E-mail berument@Bilkent.Edu.Tr. We wish to acknowledge helpful discussions with Timothy Sullivan and Bill Keech. We also appreciate detailed comments from Dennis Coates.

Received May 1997; accepted October 1997. 
Table 1. Timing of Parliament Elections in OECD Nations, 1961-1988

\begin{tabular}{|c|c|c|c|c|}
\hline Nation & $\begin{array}{l}\text { Parliament Term } \\
\text { Limit (Years) }\end{array}$ & $\begin{array}{c}\text { Average Term Length } \\
\text { (Years) }\end{array}$ & $\begin{array}{l}\text { Average Term Length } \\
\text { (\% of Limit) }\end{array}$ & Ratio of Early Elections \\
\hline Australia & 3 & 2.36 & 78.7 & $5 / 11$ \\
\hline Austria & 4 & 3.43 & 85.8 & $1 / 7$ \\
\hline Belgium & 4 & 2.97 & 74.3 & $5 / 9$ \\
\hline Canada & 5 & 2.94 & 58.8 & $5 / 9$ \\
\hline Denmark & 4 & 2.52 & 63.0 & $9 / 11$ \\
\hline Finland & 4 & 3.58 & 89.5 & $1 / 7$ \\
\hline France & 5 & 3.65 & 73.0 & $3 / 7$ \\
\hline Germany & 4 & 3.62 & 90.5 & $2 / 7$ \\
\hline Greece $^{\mathrm{a}}$ & 4 & 3.65 & 91.3 & $1 / 4$ \\
\hline Iceland & 4 & 3.40 & 85.0 & $2 / 7$ \\
\hline Ireland & 5 & 3.07 & 61.4 & $6 / 9$ \\
\hline Italy & 5 & 4.03 & 80.6 & $4 / 6$ \\
\hline Japan & 4 & 2.82 & 70.5 & $5 / 8$ \\
\hline Luxembourg & 5 & 5.00 & 100 & $0 / 5$ \\
\hline Netherlands & 4 & 3.29 & 82.3 & $2 / 7$ \\
\hline New Zealand & 3 & 2.97 & 99.0 & $0 / 8$ \\
\hline Norway & 4 & 4.00 & 100 & $0 / 6$ \\
\hline Portugal $^{b}$ & 4 & 2.25 & 56.3 & $4 / 5$ \\
\hline Spain $^{\mathrm{b}}$ & 4 & 3.00 & 75.0 & $1 / 3$ \\
\hline Sweden $^{c}$ & 4 & 3.33 & 83.3 & $1 / 3$ \\
\hline Sweden $^{\mathrm{d}}$ & 3 & 3.00 & 100 & $0 / 6$ \\
\hline Switzerland & 4 & 4.00 & 100 & $0 / 6$ \\
\hline United Kingdom & 5 & 3.24 & 64.8 & $4 / 7$ \\
\hline
\end{tabular}

Early election refers to a parliamentary election held at least one year before term expires.

a 1974-1986.

b $1976-1986$.

c 1961-1970.

d 1971-1986.

current government has a wide degree of latitude in determining when the next election will take place (subject to a maximum term length), that is, the election calendar is flexible and the actual government term lengths are variable. Using the election calendars in Mackie and Rose (1991), Table 1 shows the prevalence for member OECD nations to hold an election prior to the legal limit. Only in Norway and Switzerland is the government unable to call for early elections, and in the remaining countries, only Luxembourg and New Zealand have failed to hold at least one election more than a year before the current government's term was due to expire. In fact, 61 out of the $146(42 \%)$ elections held in the flexible-term nations between 1961 and 1988 were held at least one year early, and an additional 14 elections ( $51 \%$ total) were held at least six months early. ${ }^{1}$

Chappell and Peel (1979) and Lachler (1982) have developed theoretical models to suggest incumbent politicians with the authority to determine when an election is to be held can also use this control to their advantage. Incumbents may time the election to take place when the

\footnotetext{
${ }^{1}$ Sweden lacks an incentive to engage in OET since any newly formed government created by an early election can only fill the remaining time left from the previous government before their term will expire, and the regularly scheduled election will still be held. The only early election in Sweden occurred in 1970 when the Constitution was rewritten and the parliament term length was changed to the current three years. Removing Sweden from the calculations increases the percentage of one-year early elections to $44 \%$ and six-months early elections to $53 \%$.
} 
economy is doing well to bolster reelection. This hypothesis is referred to as opportunistic election timing (OET). Therefore, incumbents with variable electoral terms can behave strategically in either of two manners: manipulation of the economy prior to an election (PBC) or calling for an election under favorable economic conditions (OET). OET suggests a strong endogeneity problem in traditional tests of $\mathrm{PBC}$ models which do not allow for the possibility of OET.

Ito and Park (1988) present evidence that elections in Japan are more likely to be called when economic growth is high. In a series of regressions on various OECD democracies, Alesina, Cohen, and Roubini (1993) also suggest Japanese elections are endogenous to GDP growth, although they reject OET for all other countries in their sample.

There are two serious problems with interpretation of the standard single-equation methodology. First, if elections are indeed endogenous to PBC, much of the empirical literature will be untrustworthy because regression results that test PBC will be biased. Second, since Ito and Park (1988) and Alesina, Cohen, and Roubini (1993) also used single-equation regressions to test OET, these results are as likely to be biased as the PBC tests. Thus, it is still not clear which countries actually engage in OET. Although in this paper we do not test directly for the determinants of election timing, our focus remains on the importance of the OET implication for the testing of political cycles.

In this paper, we treat the endogeneity issue formally. We present standard tests for PBC and then account for endogenous elections using an instrumental variable (IV) technique. Our empirical results do not yield any support for PBC in single-equation regressions, but we uncover hidden evidence of a political monetary cycle in Japan and an inflation cycle for Britain in IV estimation. Also, both countries exhibit strong evidence of OET.

The rest of the paper is structured in the following format. In section 2 , we outline the PBC models and detail the endogeneity problem. Section 3 presents the empirical results. Conclusions appear in section 4 .

\section{Political Business Cycle Framework}

\section{Institutional Considerations}

The PBC suggests an incumbent will exploit the short-run Phillips Curve to stimulate growth and reduce unemployment in the election period even though it may result in higher inflation. In testing for political cycles, it is important to recognize institutional factors as well. For example, as mentioned above, the notion of fixed versus flexible election dates can create econometric difficulties which we address further below. In addition, election results in Japan are unlike those in most other industrialized nations. The Liberal Democratic Party (LDP) has been the majority party in parliament and has thus controlled the prime ministership and set the next election date since its inception in 1955 until 1993. The only exception was following the July 1977 election. Although the LDP held a large plurality in both the House of Consillors (upper house) and House of Representatives (lower house), they did not actually hold a pure majority of seats in either. This marks the only time prior to 1993 that the LDP was not the pure majority party in parliament, ${ }^{2}$ but support from several independents allowed the LDP to

\footnotetext{
${ }^{2}$ The LDP held only $49 \%$ of the seats in the House of Representatives following elections in December 1976, October 1979, and December 1983 but still controlled a large majority of seats in the House of Consillors. Our sample ends prior to the large loss of seats suffered by the LDP in the July 1989 election.
} 
retain control of the Diet and they successfully regained a pure majority of seats in both houses following the June 1980 election (Banks 1993). Only once during this time period did they decline to call an early election-when the December 1976 election was held the maximum four years after the previous election.

Under the hypothesis set forward here, the LDP may have been very successful at retaining power due to effective manipulation of the economy. The government of Japan is in an especially good position to alter aggregate variables due to their very dependent central bank (Cukierman 1992). Alternatively, the prosperity of the LDP may be due to successful manipulation of the election date. However, a party that is very secure in its political outlook under ordinary circumstances may not need to resort to expansionary policies (Frey and Schneider 1978) or intentional election date manipulation to win reelection.

Thus, it may be interesting to contrast the results of Japanese elections with those of Britain, where party control of parliament alternated several times during our sample, which suggests British elections are more competitive in general. Under the PBC scenario, this implies British governments have been less successful in manipulation of short-run economic targets (perhaps due to a more independent central bank) than their Japanese counterparts. Competitive elections in Britain also suggest there may be more incentive to attempt manipulation. Thus, we consider both possible business cycles and policy cycles in our empirical tests.

\section{Primary Methodology}

Typically, PBC models are tested by estimating

$$
Y_{t}=\alpha+\beta X+\delta D_{t}+v_{t}
$$

where $Y_{t}$ is the cycle variable in question, $\mathrm{X}$ is a matrix of control variables, $D_{t}$ is an election dummy, and $v_{t}$ is an error term at time $t$. The election dummy in Equation 1 is simply expected to mark the timing of the cycle.

Since McCallum (1978), most empirical tests for PBC have relied on the assumption that the macroeconomic variables under consideration are generated by a covariance-stationary process that can be estimated by a finite autoregressive regression. Hence, we model the cyclical variables accordingly. ${ }^{3}$ More specifically we will estimate the following model:

$$
Y_{t}=\alpha+\sum_{i=1}^{p} \beta_{i} Y_{t-i}+\delta D_{t}+v_{t}
$$

This intervention analysis approach tests for changes in the underlying process due to an election. We are interested primarily in the sign and significance of the estimate of $\delta$.

\section{Incorporating $O E T$}

The ordinary least squares (OLS) regression procedure requires the residuals and the righthand side variables of an equation to be uncorrelated. Thus, OLS yields biased estimates when

\footnotetext{
${ }^{3}$ The PBC empirical literature relies primarily on reduced-form autoregressive time-series models. Because we are not interested in identifying the other factors that also affect the various macroeconomic variables, we rely on the autoregressive procedure to determine how elections affect the behavior of the cyclical variable in question.
} 
the right-hand side variables are influenced by the left-hand side variable and, consequently, the residuals of the equation.

As explained above, incumbents may call an election when economic conditions are favorable (Lachler 1982). Our cyclical variables, therefore, may influence the election timing. Assuming election timing is exogenous and performing OLS on Equation 2 may yield biased results. The asymptotic bias from OLS estimation is equal to $\sigma_{D_{t}, V_{t}} / \sigma_{D t}^{2}$. In the cases where election timing is purely exogenous, $\sigma_{D_{t}, V_{t}}=0$, indicating OLS yields a consistent estimate of $\delta$. But if the election dummy is correlated with the residual, OLS estimation produces an asymptotic bias directly proportional to the degree of covariance.

To test for endogenous elections, Alesina, Cohen, and Roubini (1993) estimate another regression of the form

$$
D_{t}=\lambda+\phi Z_{t}+\gamma Y_{t}+u_{t}
$$

to observe how the election timing is set. Here $Z_{t}$ is a vector of independent variables and $u_{t}$ is assumed to be a random error term. The significance of the estimate of $\gamma$ is used to determine if $Y_{t}$ (the macroeconomic cycle variables) influences $D_{t}$. However, the simultaneity problem is still present. Since election timing affects macroeconomic variables in Equation 2, there must also be correlation between the residual term and some of the right-hand side variables in Equation 3. Hence, the estimates in Equation 3 are biased and results from this procedure cannot be trusted.

Ito and Park (1988) use a two-stage procedure to estimate Equation 3. However, this is not done to account for endogeneity. Instead, they estimate

$$
D_{t}=\kappa+\phi_{1} \dot{Z}_{t}+\phi_{2} \dot{e}_{Z t}+\gamma_{1} \dot{Y}_{t}+\gamma_{2} \dot{e}_{Y t}+w_{t},
$$

where $\dot{Z}_{t}, \dot{e}_{Z t}$ represent predicted $Z_{t}$ and residuals from a first-stage regression on $Z_{t} ; \dot{Y}_{t}, \dot{e}_{Y t}$ are similarly defined for a first-stage regression on $Y_{r}$. Their intent was to separate anticipated policy changes from random shocks that create GDP growth. ${ }^{4}$ By including residuals from first-stage regressions, Equations $3^{\prime}$ and 3 contain the same information (although disaggregated), so any endogeneity bias inherent in Equation 3 remains inherent in Equation $3^{\prime}$. In the above equations, all right-hand side variables were assumed to be exogenous to the election date, but as explained above, this assumption may not be valid.

In this paper, we test for the endogeneity of election timing in Equation 2 by using a Hausman (1978) procedure via an IV technique. If we find the presence of endogeneity, we then use an instrumental variable for $D_{t}$ in Equation 2.5 An added advantage to this approach is that under IV estimation, we do not need a structural model for Equation 3, which is likely to be misspecified. ${ }^{6}$

Hausman's test considers the difference in two estimates. The first estimate must be consistent and asymptotically efficient under the null but inconsistent under the alternative hypothesis. The second estimate is not asymptotically efficient under the null but consistent under both the null and alternative hypotheses. Here, the null hypothesis we are concerned with is that $D_{t}$

\footnotetext{
${ }^{4}$ Their procedure is similar to Mishkin's (1983) rational expectations approach to modeling the economy.

${ }^{5}$ Direct substitution of the endogenous variable with its instrumental projection leads to biased standard errors. In the IV tests for Tables 2 and 4, we have used the INST command in Rats 4.0, which automatically adjusts the variancecovariance matrix appropriately.

${ }^{6}$ Alesina, Cohen, and Roubini (1993) admit skepticism of their OET tests due to possible misspecification.
} 
is exogenous. Therefore, estimated coefficients from OLS would be unbiased, consistent, and efficient if the null were satisfied. The alternative is an endogeneity problem, in which case performing OLS leads to inconsistent estimation, but IV consistently estimates the parameters. Although we will report both estimators for all regressions, we rely on OLS on efficiency grounds for those cases where the Hausman test does not reject the null.

We use Hausman's (1978) second test, which is a single-equation $F$-test. In order to perform the Hausman test, we include an instrumental variable in Equation 2, that is,

$$
Y_{t}=\alpha+\sum_{i=1}^{p} \beta_{i} Y_{t-i}+\delta D_{t}+\delta^{*} D_{t}^{*}+v_{t}
$$

where $D_{t}^{*}$ is an instrumental variable for $D_{t}$. An $F$-test is used to test the restriction $\delta^{*}=0$. If the test statistic is significant, we reject the null that OLS estimates on Equation 2 are consistent. Otherwise, we do not reject OLS as the appropriate way to estimate the model.

\section{Empirical Testing}

\section{Model Specification}

In our empirical tests, we consider several cyclical variables, which include inflation, GDP, real GDP, government spending, and money supply. Each variable is defined as the growth rate over the previous quarter. The lagged variables must contain at least four quarters due to the seasonal nature of the data, that is, $p \geq 4$ in Equation 2. To determine the optimal lag structure, we employ Schwarz (1978) criterion, which, for our sample, suggests no additional lags are necessary.

The election dummy $D_{t}$ is defined as 1 in the election quarter and 0 otherwise. This is a strict version of Nordhaus (1975), which seeks peaks (or troughs) in the cycles at the time of the election. Single-period comparisons are typical in testing (Nordhaus 1975; Tufte 1978; Ito and Park 1988; Heckelman and Whaples 1996), but alternative specifications are also often considered to adjust for early strategic behavior and lags from policy effects (McCallum 1978; Grier 1987; Keil 1988; Alesina and Roubini 1992; Alesina, Cohen, and Roubini 1992, 1993). Our reported results are robust to several alternative election variable definitions.

Our choice of instruments is supported by strategic election theory. If the primary goal of political parties is simply to retain power, then elections should be called when the incumbent government popularity is high. The key assumption in PBC is predicated on the strength of the economy comprising a major component of government popularity. Despite the widespread availability of popularity information, parties remain uncertain concerning their electoral success since polls are not perfect predictors of voting outcomes. We can thus expect the ruling party to consider information regarding the economy in addition to independent poll information when strategically choosing an election date to maximize their chance of reelection. Since there is always a positive probability of being voted out of office in any election, Balke (1990) shows the opportunity cost of calling an early election declines as the legal deadline approaches. Thus, for each equation, we use as instruments ${ }^{7}$ two year lags of the dependent variable to determine

\footnotetext{
${ }^{7}$ Tests for instrument suitability based on Bound, Jaeger, and Baker (1995) generally support our choice of instrument sets. For brevity sake, we do not produce the results here, but note that we generally find our instrument sets are correlated with $D_{t}$ and artificial regressions suggest they are not correlated with $v_{t}$. Also, Lagrange multiplier tests do not reject our overidentified model. Full test results for each equation are available on request.
} 
strength of the economy; current and three lags on the governmental approval rate which determines the incumbent government popularity ${ }^{8}$ and a counter variable that measures the number of quarters since the last election to represent time removed from the maximal term length. ${ }^{9}$

When testing for endogeneity, we expect variables over which the government has less control are more likely to cause elections to be endogenous. Thus, in the government spending regressions, elections should always be exogenous, not endogenous (Keil 1988). Further, money supply equations are more likely to have election timing endogenous for Britain than Japan since Britain's central bank is considered to be more independent than Japan's. ${ }^{10}$ Finally, elections are most likely to be endogenous to the macroeconomic outcomes variables of GDP, real GDP, and inflation, relative to the policy variables of spending and money supply.

\section{Data}

Our sample includes quarterly observations from 1962:2 to 1989:1 for Japan, and quarterly observations from 1960:1 to 1990:3 for the U.K. All economic variables for both countries are taken from International Monetary Fund-International Financial Statistics. The Japanese Cabinet approval rate is from Yoron Chosa Geppo (the monthly surveys of public opinion). ${ }^{11}$ The U.K. prime minister approval rate is from Market and Opinion Research International.

\section{PBC Tests in Japan}

OLS estimates from PBC models on Japan using Equation 2 are presented in Table 2. The coefficient on $D_{t}$ is not significant in any of the regressions, which implies elections do not affect the growth rate of any of the variables. This corroborates OLS regressions in Ito and Park (1988) and Alesina, Cohen, and Roubini (1992). However, Hausman tests based on Equation 4 suggest this conclusion may be premature. Given our choice of instruments, the Hausman statistic is significant for every regression except spending. Thus, there is reason to believe election timing is an endogenous variable in these regressions, in which case the OLS regressions are biased.

Endogenous election timing indicates Japanese incumbents used the economic conditions to guide their decision of when to call an election. This supports the theory of Lachler (1982) and empirical evidence in Ito and Park (1988) and Alesina, Cohen, and Roubini (1993). Election timing is found to be exogenous in the spending regression, and the OLS estimates reveal that fiscal policy was not manipulated specifically around elections.

The Hausman tests suggest the other regressions need to be estimated via IV to obtain consistent estimates. These results are presented in Table 3. Controlling for endogeneity, we find evidence of a political monetary cycle. The central bank of Japan apparently attempts to

\footnotetext{
${ }^{8}$ Probit regressions using one-year lags indicate a second year of lags on either the cyclical variable or approval rating, but not both, are correlated with the election timing variable. Because we do not have as many lagged observations on approval rating as for the cyclical variable, we use extended lags on the cyclical variable to preserve degrees of freedom.

${ }^{9}$ Balke's (1990) model actually suggests a more complicated functional form for time than the simple linear approximation we employ since opportunity costs are assumed to decrease at a increasing rate. We leave nonlinear representations as an empirical question to be resolved elsewhere, but note that the tests for instrument suitability described in note 7 support our final choice set.

${ }^{10}$ Specifically, Cukierman (1992) ranks Britain's central bank independence to be twice that of Japan's (on a relative scale).

${ }^{11}$ We thank Motoshi Suzuki for providing the approval rate data for Japan.
} 


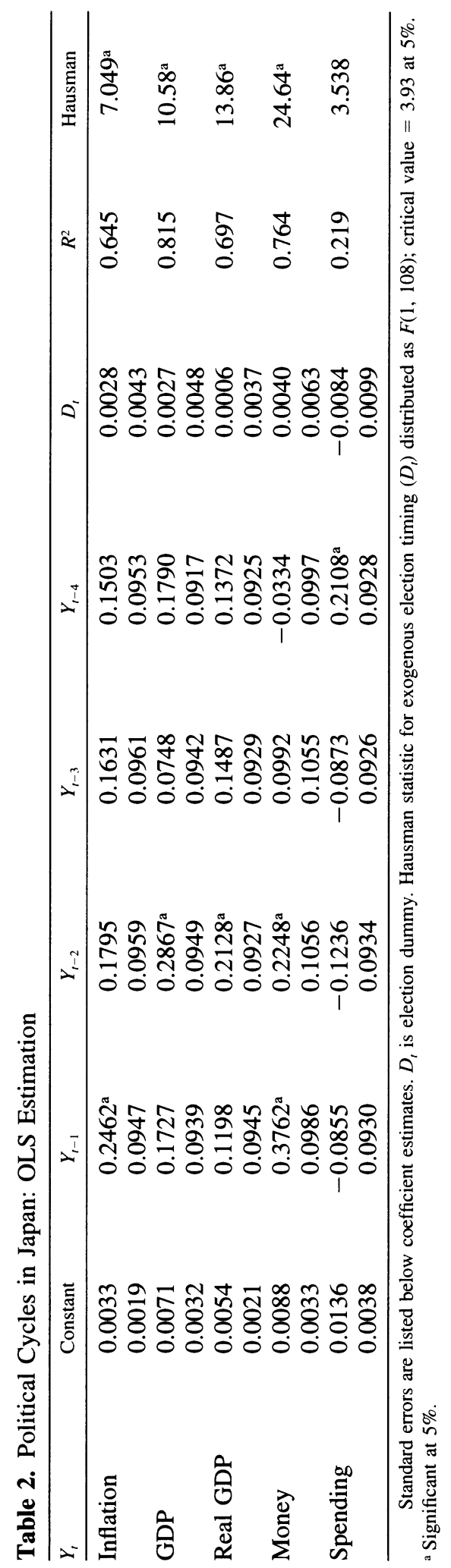


Table 3. Political Cycles in Japan: IV Estimation

\begin{tabular}{lccccccc}
\hline$Y_{t}$ & Constant & $Y_{t-1}$ & $Y_{t-2}$ & $Y_{t-3}$ & $Y_{t-4}$ & \multicolumn{1}{c}{$D_{t}$} & $R^{2}$ \\
\hline Inflation & 0.0029 & $0.2700^{\mathrm{a}}$ & 0.1682 & 0.1674 & 0.1499 & 0.0018 & 0.644 \\
& 0.0021 & 0.1002 & 0.1007 & 0.1001 & 0.0975 & 0.0085 & \\
GDP & 0.0075 & $0.2082^{\mathrm{a}}$ & $0.2867^{\mathrm{a}}$ & 0.0316 & 0.1762 & 0.0007 & 0.816 \\
& 0.0034 & 0.0972 & 0.0953 & 0.0956 & 0.0942 & 0.0097 & \\
Real GDP & 0.0050 & 0.1506 & $0.2537^{\mathrm{a}}$ & 0.1462 & 0.0417 & 0.0100 & 0.682 \\
& 0.0022 & 0.1020 & 0.0989 & 0.0980 & 0.1015 & 0.0083 & \\
Money & 0.0064 & $0.4607^{\mathrm{a}}$ & 0.1343 & 0.1442 & -0.0458 & $0.0300^{\mathrm{a}}$ & 0.746 \\
& 0.0038 & 0.1136 & 0.1194 & 0.1156 & 0.1076 & 0.0139 & \\
Spending & 0.0152 & -0.1104 & -0.1597 & -0.0976 & $0.2078^{\mathrm{a}}$ & -0.0233 & 0.192 \\
& 0.0044 & 0.0983 & 0.1011 & 0.0974 & 0.0985 & 0.0216 & \\
\hline
\end{tabular}

Standard errors are listed below coefficient estimates. $D_{t}$ represents the instrumental variable for election timing using second year of lags of $Y_{t}$, current and three quarter lags of government popularity rating, and counter for number of quarters since previous election as additional instruments.

a Significant at $5 \%$.

aid the current government through easy monetary policy, but there is no corresponding effect on inflation or growth. As noted, OLS regressions in Ito and Park (1988) and Alesina, Cohen, and Roubini (1992) were not able to find evidence of a political monetary cycle in Japan. Panel regressions in Alesina, Cohen, and Roubini (1993) also reject a monetary cycle for OECD nations using monetary base, but a similar regression using M1 in Alesina, Cohen, and Roubini (1992) supports an electoral cycle.

Since the Japanese central bank is considered to be relatively dependent, it may be less overt for the government to alter aggregate demand through changes in monetary, rather than fiscal, policy. However, these adjustments appear to be ineffective in altering output growth.

A final note on Japan concerns the 1980 election which was called by the parliament as a no-confidence vote. Thus, it was not strategically chosen by the prime minister but may have been strategically chosen by the outside parties. ${ }^{12}$ The current government in this case would not have been able to manipulate the economy since they did not plan on the election. This could taint our results. To account for this special election, we next omitted the observation by including a dummy variable for the 1980 election and also tried recoding it as a nonelection. Those regressions (not reported) all support the results we find in Tables 2 and 3.

\section{$P B C$ Tests in Britain}

The only alterations to the regressions for Britain are to be found in the money cycle tests. Britain changed their definition of M1 in 1987:1, which would upset the pattern during this transition. We therefore include a dummy variable $M_{t}$ to capture the institutional change in this quarter. In effect, $M_{t}$ represents the residual for that observation.

Following the same procedure as for Japan, we first estimated OLS regressions on the cyclical variables for the U.K., which are presented in Table 4. Again, we find no evidence to support PBC activity in this country, which is consistent with OLS tests on Britain in Alesina, Cohen, and Roubini (1992). However, Hausman tests again suggest these regressions, except

12 The no-confidence vote passed only due to the absence of several LDP party members (Ito and Park 1988; Banks 1993). 


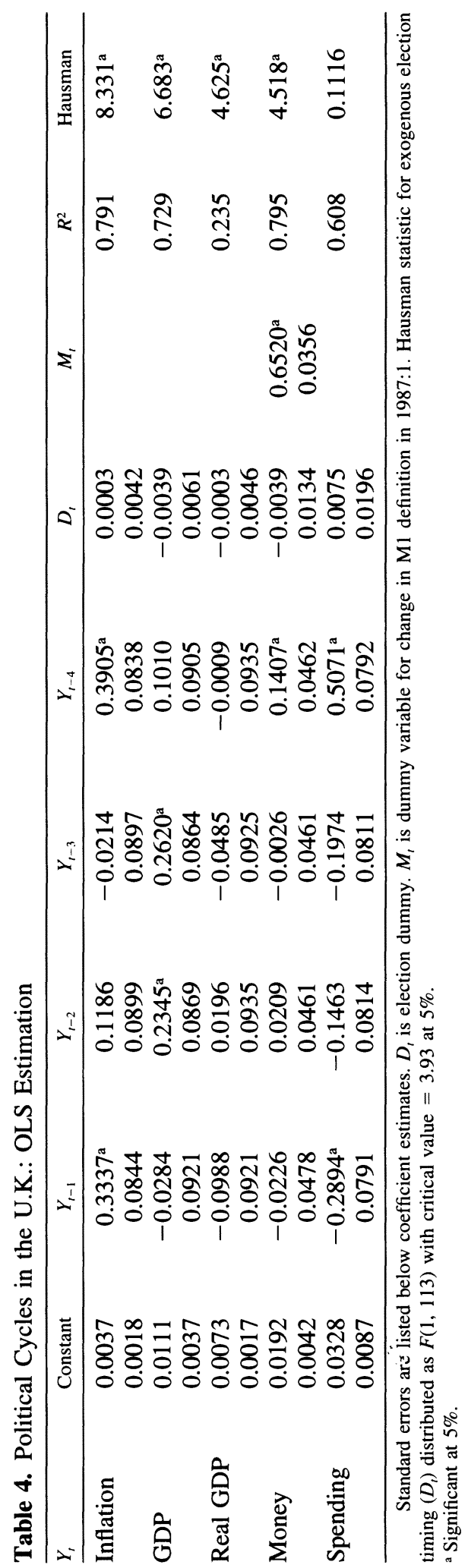


for spending, suffer from endogeneity. We therefore only have faith in the spending regression, which does not support a political policy cycle.

Table 5 presents the IV estimates for the UK. The election dummy coefficient is not significant in either the output or money regressions. The coefficient is significant in the inflation regression, but of the opposite sign as predicted by $\mathrm{PBC}$. This anomaly may be explained under a different interpretation of PBC.

In the PBC model, both inflation and unemployment yield disutility to voters. Nordhaus (1975) assumed governments can directly control unemployment and inflation is simply a residual change from movement along the short-run Phillips Curve. Thus, the traditional PBC model predicts lower unemployment and higher inflation. This choice, though, depends on the slope of the Phillips Curve and voter utility functions.

A relatively steep slope would make the opportunity cost of lower unemployment too high (in terms of higher inflation). Keech's (1995) test for PBC in the U.S. compares the so-called misery index, which is simply the sum of unemployment and inflation rates. This implicitly assumes both variables have an equal weight in voter utility functions, so lower inflation with a less than proportional increase in unemployment lowers the misery index.

Popularity function estimates typically do not support this conjecture. Although Hibbs (1987b) estimates that voters place an equal weight on both inflation and unemployment, a more compelling case is made by Kirchgässner (1985), who, by estimating through time-series applications, finds that voters place much greater importance on inflation than unemployment. ${ }^{13}$

Thus, it may be in the government's best interest to lower inflation rather than lower unemployment and be saddled with higher inflation as a consequence (Soh 1986). ${ }^{14}$ However, we find no evidence of manipulation of fiscal or monetary instruments nor is there any change in either nominal or real growth.

\section{Conclusions}

To summarize, testing for endogeneity through Hausman tests yields strong evidence of OET in both Japan and Britain. The evidence for PBC is much more limited and, in general, we reject the implications from the traditional PBC for these two democracies. However, we do find evidence of monetary cycles in Japan, but policy instrument manipulation of either money or government spending appears to be absent in Britain.

Our empirical results indicate OET exists in both countries. In addition, some electoral cycles (money cycle in Japan and inflation cycle in the U.K.) were masked in the OLS regressions. This suggests that empirical evidence that relies on OLS suffers from endogeneity bias. The money cycle in Japan under IV estimation contrasts with Ito and Park (1988), who found no evidence of policy instrument manipulation in their OLS regressions.

The endogeneity patterns we uncover are consistent with our expectations. Politicians may realize how difficult it is to alter the macroeconomy (they do not directly set the unemployment rate, as assumed in Nordhaus [1975]) and instead wait until the economy is strong to call an

\footnotetext{
${ }^{13}$ Similar results are found by Kramer (1971), Chappell (1990) and Suzuki (1992) using standard regression estimates.

${ }^{14}$ A similar explanation is suggested by Grier (1987), who claims an expansionary monetary policy cycle is consistent with no change in unemployment and lower inflation before an election. He suggests this type of deflationary cycle supports the political business cycle model. We do not, however, find evidence of a political monetary cycle for Britain to coincide with the lower inflation.
} 


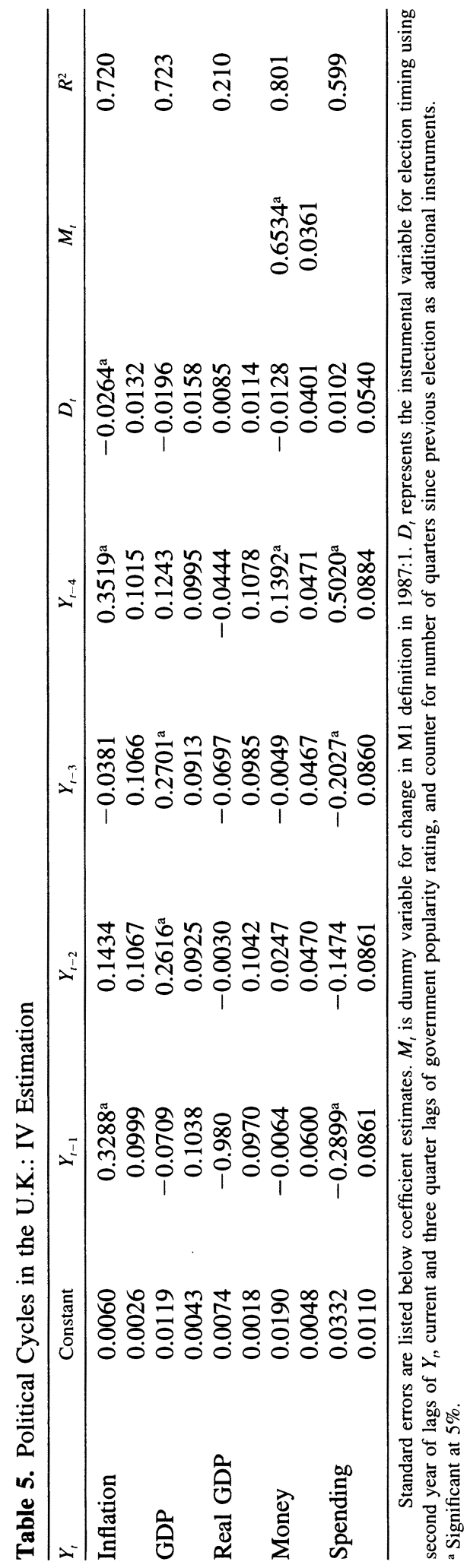


election. This is consistent with the findings of Ito and Park (1988) for Japan and confirms the suspicions of Keil (1988) for Britain.

The finding of OET has two important implications. First, since these governments have an additional strategic component, we might expect fewer attempts at manipulation of the economy and therefore a more stable economy than in those democracies where term length is predetermined. This is directly relevant for the growing literature on the connection between democracy and growth. These studies typically group several democracies together to contrast against authoritarian governments. The importance of OET and PBC suggests democracy variables need to be disaggregated between fixed and flexible electoral term nations to avoid misspecification. Second, it also implies party representation should be more stable under governments that have the option of calling an early election. There will be more elections, but because the party in control can choose the most opportune time, they should more easily be able to retain power. Incumbents without this option can only rely on economic manipulation, which is far more difficult (impossible when voters have rational expectations). We expect this to be a promising avenue for future empirical research.

Finally, a comparison between Japan and Britain on political monetary cycles is consistent with Cukierman's (1992) claim that Japan has one of the most dependent central banks of all the OECD nations. Given that an election has been called for, it is more likely that a dependent central bank will help the current government through expansionary monetary policy, which we find for Japan but not for Britain. This makes sense in lieu of the relative independence of Britain's central bank.

\section{References}

Alesina, Alberto, Gerald D. Cohen, and Nouriel Roubini. 1992. Macroeconomic policy and elections in OECD democracies. Economics and Politics 4:1-30.

Alesina, Alberto, Gerald D. Cohen, and Nouriel Roubini. 1993. Electoral business cycles in industrial democracies. European Journal of Political Economy 9:1-23.

Alesina, Alberto, and Nouriel Roubini. 1992. Political cycles in OECD democracies. Review of Economic Studies 59: 663-88.

Balke, Nathan S. 1990. The rational timing of parliamentary elections. Public Choice 65:201-16.

Banks, A., ed. 1993. Political handbook of the world. Binghamton, NY: CSA Publications.

Bound, John, David A. Jaeger, and Regina M. Baker. 1995. Problems with instrumental variables estimation when the correlation between the instruments and the endogenous explanatory variable is weak. Journal of the American Statistical Association 90:443-50.

Chappell, D., and D. A. Peel. 1979. On the political theory of the business cycle. Economics Letters 2:327-32.

Chappell, Henry W., Jr. 1990. Economic performance, voting, and political support: A unified approach. Review of Economics and Statistics 72:313-20.

Cukierman, Alex. 1992. Central bank strategy, credibility and independence. Cambridge, MA: MIT Press.

Fair, Ray C. 1978. The effect of economic events on votes for president. Review of Economics and Statistics 60:159-72.

Frey, Bruno, and Freidrich Schneider. 1978. An empirical study of politico-economic interaction in the United States. Review of Economics and Statistics 60:174-83.

Grier, Kevin B. 1987. Presidential elections and federal reserve policy: An empirical test. Southern Economic Journal $54: 475-86$.

Hausman, Jerry A. 1978. Specification tests in econometrics. Econometrica 46:1251-71.

Heckelman, Jac, and Robert Whaples. 1996. Political business cycles before the Great Depression. Economics Letters 5: 247-51.

Hibbs, Douglas A. 1987a. The American political economy. Cambridge, MA: Harvard University Press.

Hibbs, Douglas A. 1987b. The political economy of industrialized democracies. Cambridge, MA: Harvard University Press.

Ito, Takatoshi, and Jin Hyuk Park. 1988. Political business cycles in the parliamentary system. Economics Letters 27: 233-8. 
Keech, William R. 1995. Economic politics. New York: Cambridge University Press.

Keil, Manfred W. 1988. Is the political business cycle really dead? Southern Economic Journal 55:86-99.

Kirchgässner, Gebhard. 1985. Rationality, causality, and the relation between economic conditions and the popularity of parties. European Economic Review 28:243-68.

Kramer, Gerald H. 1971. Short term fluctuations in U.S. voting behavior, 1896-1964. American Political Science Review 65:131-43.

Lachler, Ulrich. 1982. On political business cycles with endogenous election dates. Journal of Public Economics 17: 111-7.

Mackie, Thomas T., and Richard Rose. 1991. The international almanac of electoral history. 3rd edition. Washington, DC: Congressional Quarterly.

McCallum, Bennett T. 1978. The political business cycle: An empirical test. Southern Economic Journal 44:504-15.

Mishkin, Frederic S. 1983. A rational expectations approach to macroeconometrics. Chicago: University of Chicago Press.

Nordhaus, William D. 1975. The political business cycle. Review of Economic Studies 42:169-90.

Schwarz, Gideon. 1978. Estimating the dimension of a model. Annals of Statistics 6:461-4.

Soh, Byung Hee. 1986. Political business cycles in industrialized countries. Kyklos 39:31-46.

Suzuki, Motoshi. 1992. Political business cycles in the public mind. American Political Science Review 86:989-96.

Tufte, Edward R. 1978. Political control of the economy. Princeton, NJ: Princeton University Press. 